\title{
Rediscovery of Premna lucidula Miq (Lamiaceae) in Mount Nglanggeran Gunungkidul
}

\author{
Widodo $^{1}$, Muhammad Jafar Luthfi ${ }^{2}$ \\ ${ }^{1}$ Biology Education Department, ${ }^{2}$ Biology Department, Faculty of Science and Technology, UIN Sunan Kalijaga Yogyakarta \\ Jl. Marsda Adisucipto No 1 Yogyakarta 55281, Indonesia. Tel. +62-274-540971, Fax. +62-274-519739. \\ ${ }^{1}$ Email: wwidodo594@gmail.com
}

\begin{abstract}
Widodo, Luthfi M J. 2017. Rediscovery of Premna lucidula Miq (Lamiaceae) in Mount Nglanggeran Gunungkidul. Proc Internat Conf Sci Engin 1: 59-65. Premna lucidula Miq (Lamiaceae) were found at S 07 50' 29.4"; E 110 32' $10.2^{\prime}$ " about 497 meter above sea levelin mount Nglanggeran, Gunungkidul, Yogyakarta. Identification was based on literature and herbarium specimen. The research was conduct using exploration method, morphological observation, and specimen collection. Premna lucidula is a shrub or small scandent tree. The specific character for its identification was inflorescence, leaf, fruit and stem structure. This paper described the important character of leaf, stem, flower, and fruit of Premna lucidula in mount Nglanggeran Gunungkidul Yogyakarta for support Backer \& Bakhuizen (1965) description. Premna lucidula were recorded in Pacitan (Central Java) by Horsefied hundred years ago. The lack of subsequent report on this species was due to misidentification or ignorance of the importance of taxonomic research. Accurate description and examination of any plant species were needed for its conservation and awareness of public to local biodiversity.
\end{abstract}

Keywords: Premna lucidula, Lamiaceae, Verbenaceae, Mount Nglanggeran

\section{INTRODUCTION}

In exploration for identification of plants in Nglanggeran mountain in 2009, the authors found bushy climbing plants at location $\mathrm{S} 07^{\circ} 50$ '29.4 "; E $110^{\circ} 32$ ' 10.2 ", 497 meters above sea level, characterized by an unpleasant odor of flowers, the chrushed leaves also produced smell like the smell of the flowers. The authors suspect that the plant is a member of the Celstraceae Family based on the characteristics of lenticels, but based on the structure of inflorescence and leaf position on the stem, the authors suspect this plant is a member of Verbenaceae. Periodical observations by the authors were carried on. Until 2015, this plant has not been successfully identified. During observation one of the authors realized that the odor of leaf squeeze from this plant is similar to the smell of squeezed leaves Premna oblongata (Lamiaceae). Furthermore, the authors make intensive observation and search of literature, especially Flora of Java (Backer \& Bakhuizan, 1965). The author suggested that this plant is a member of the genus Premna. Backer and Bakhuizan (1962) listed and described that there are 8 types of Premna: Premna tomentosa, Premna capitata, Premna oblongata, Premna parasitica, Premna rotundifolia, Premna corymbosa, Premna lucidula, Premna pubescens. Description Backer \& Bkhuizen (1965) about the characteristics of each species of the genus Premna lead to the conclusion that this plant is Premna lucidula Miq. Description Backer \& Bakhuizen (1962) are as follows:

"Corolla glabrous outside, greenish white; upper lip 2-2 $1 / 2 \mathrm{~mm}$, lower lip. C $3 \mathrm{~mm}$; corymbs (inclusive of $3 / 4-1^{1 / 2}$ cm peduncle) 3-6 cm, brown hairy; pedicels $1 / 2-3 / 4 \mathrm{~cm}$; calyx subbilabiate; upper lip shorthly 3 dentate, lower one 2 lobed; drupe globose, c. 1/2 cm diam. Young branches pale, thinly short hairy (on the nodes more densely so); leaves ovate-oblonng (rare subovateoblong), from a rounded, obtuse, or cuneate base, rather long-acuminate, entire or irregularly dentate in upper half, short-hairy on the surface of the midrib; otherwise subglabrous on both surface, $7-15 \mathrm{~cm}$ by $31 / 2-61 / 2 \mathrm{~cm}$; petiole $11 / 4-41 / 2 \mathrm{~cm}$. Shrub or small tree".

Information about this plant on internet is almost non-existent. Lack of information about Premna lucidula and description of Backer \& Bakhuizen on its features (short hairy on the flower stalk, young branches, leaf vein) had confused the authors and encouraged to match to herbarium type specimen. Matched Herbarium BM000901525 (MNH, 2017) convinced the authors that the plant $\mathrm{I}$ found in Nglanggeran mountain at location S $07^{\circ} 50$ '29.4 "; E $110^{\circ} 32$ '10.2, 497 meters above sea level is Premna lucidula. Herbarium type is Premna lucidula, Type: Indonesia, Java, in Pacitan, Horsfield s.n. (BM lectotype, selected by Rajendran \& Daniel (1992), isolectotype BM 2 sheets). This paper aimed to present Premna lucidula's findings in Nglanggeran Gunungkidul Mountain, describe the characteristics, completed the description of the features submitted by Backer \& Bakhuizen that would strengthen and support the findings of this species by Horsfield hundreds of years ago in Pacitan East Java.

\section{MATERIALS AND METHODS}

\section{Equipments and Materials}

Equipment for observation and collection comprises: digital camera Sony NEX F3, digital cameras Sony 
Cyber-Shot DSC-W180 digital camera Canon DSLR, rulers, micrometers, calipers, plastic container, scissors, cutter, label paper, GPS (Global Positioning System), dried herbarium collection equipment, bottles, stereo microscope Nikon SMZ 1500 equipped with a camera, Nikon light microscope equipped with Nikon Eclipse 50 DSF1.

Materials for observation and collection comprises: Aquadest, Alcohol 70\%, FAA solution (Formalin Acetic Alchohol).

\section{Procedures}

1. Observe and take macro and microphotograph of specimen under natural conditions at the site, herbarium, and flower detail.

2. Preparation of dried herbarium

3. Early identification of specimens for members Verbenaceae based on the book Flora of Java Vol. 2 (Backer and Bakhuizen, 1965).
4. Identify Verbenaceae specimen based on existing literature, including checking and matching with herbarium type.

\section{RESULTS AND DISCUSSION}

On the $6^{\text {th }}$ August 2012 visit, the authors found the plant in a leaves falling condition in the dry season (Figure 1). Then on November 25, 2012, this plant start flowering (buds) (Figure 2). Flower bud structures are compound bunches. On this observation the authors observed that this plant is a member of the family Verbenaceae (Now family verbenaceae merge to the Family Lamiaceae). Observations on November 25, 2013 found this plant in bloom (Figure 3).

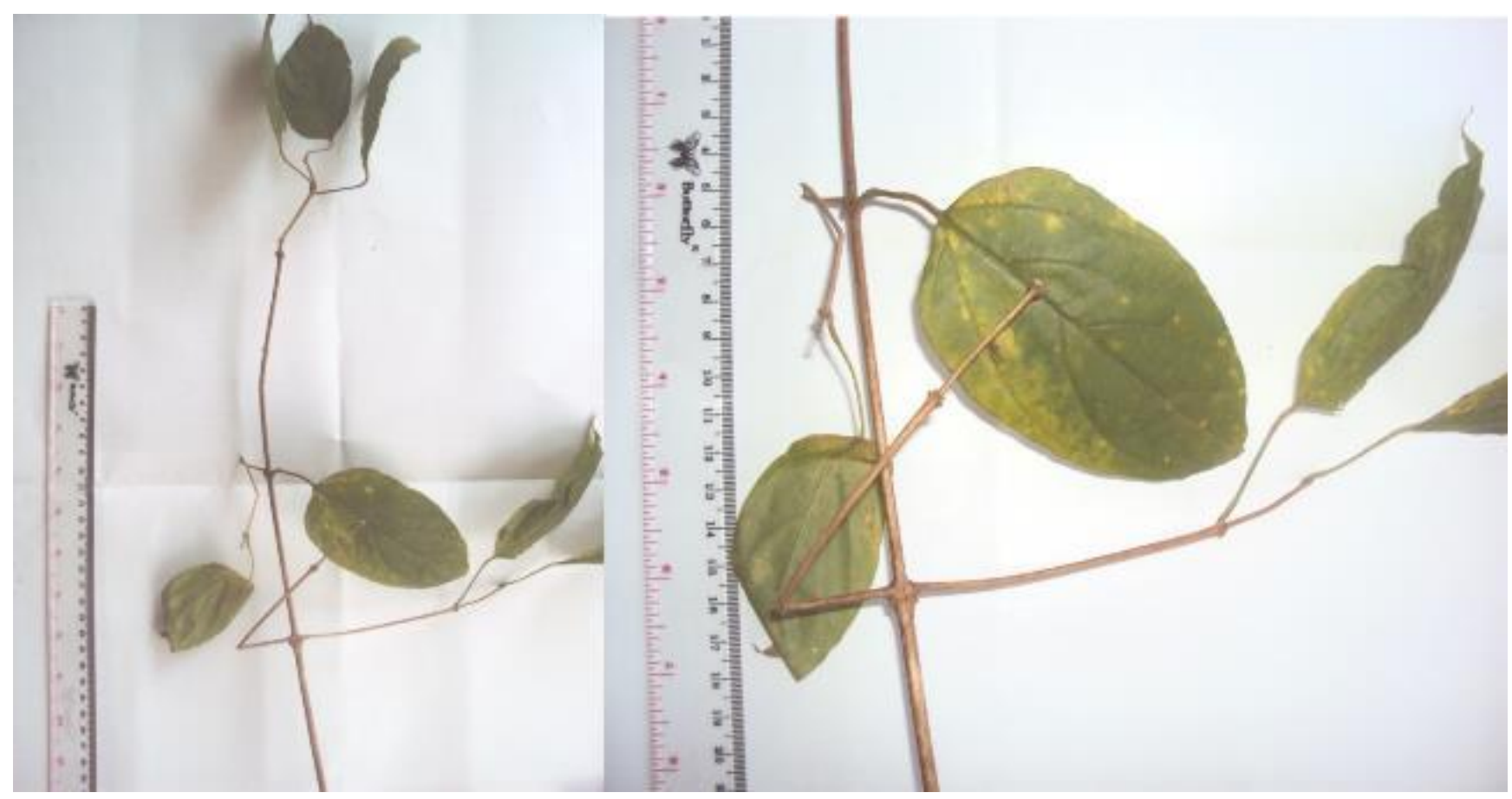

Figure 1. Leaves falling twigs of Premna lucidula from Mt. Nglanggeran. 


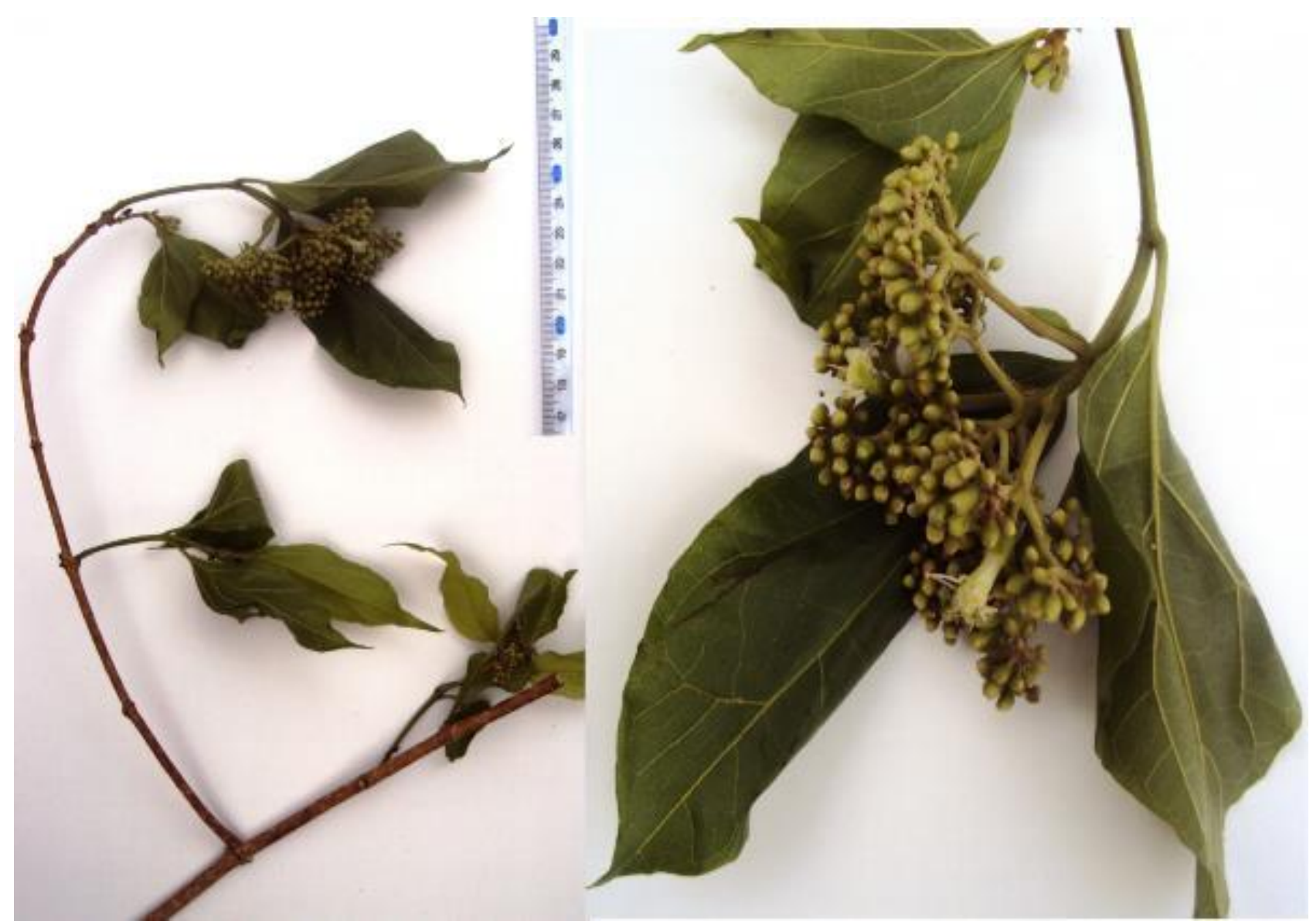

Figure 2. Twigs of Premna lucidula with flower buds.

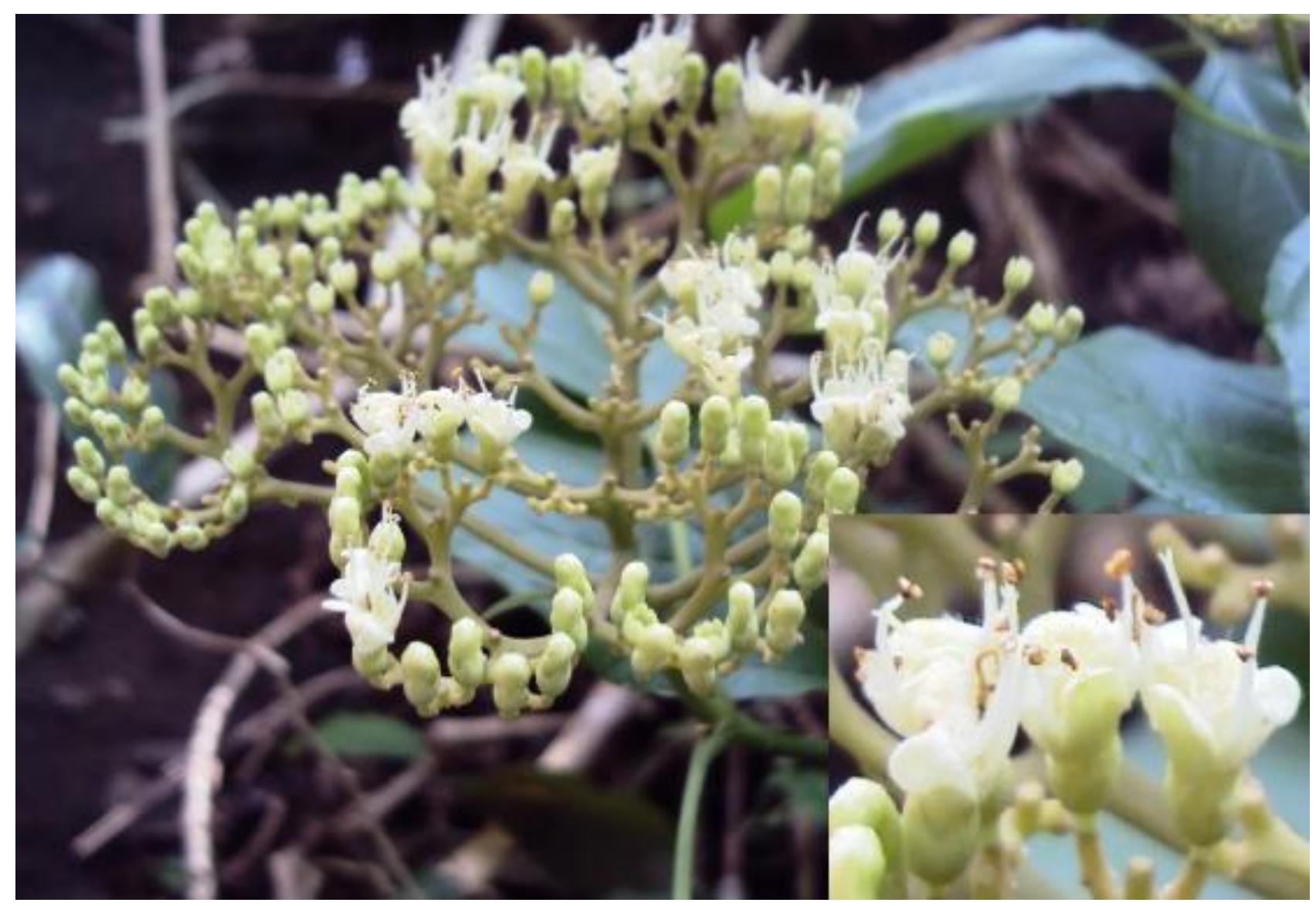

Figure 3. Premna lucidula inflorescence of corymbosa type. 
On $13^{\text {th }}$ November $2016,16^{\text {th }}$ November $2017,3^{\text {th }}$ March 2017, we observed detail of habitus, stem, leaves, flowers, specimen secara and collected the sampel for herbaria. Detail of observation are showed in figure 4.
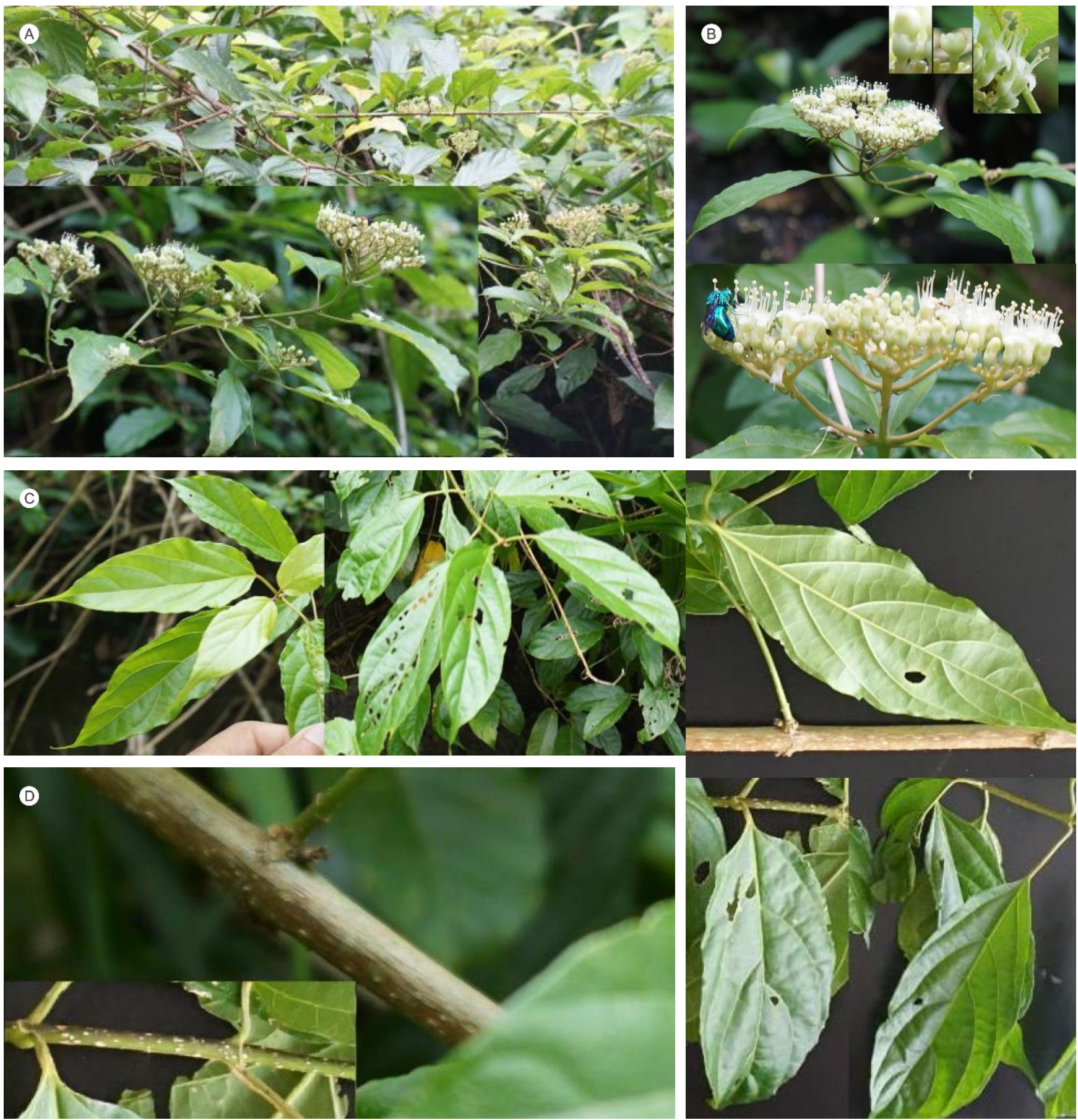

Figure 4. Premna lucidula from Mt. Nglanggeran. A. Habitus, B. Inflorescence, Insert: flower C. leaves, Insert: Upper and lower surface. D. stem, Insert Lenticel on surface.

The results of the searching in the Flora of Java (Backer \& Bakhuizen, 1965)) in the Verbenaceae family genera revealed that most likely this plant is Premna. Based on the leaves and floral morphology, it is very probable that the plant species is Premna lucidula Miq.
From herbaria matching, it is matched with BM type herbarium 00001424, BM000901425, BM000901426 (Natural History Museum, 2017) that both exhibit identical features (Figure 4). Type herbarium were collected from pacitan and collected by Horsifield. 

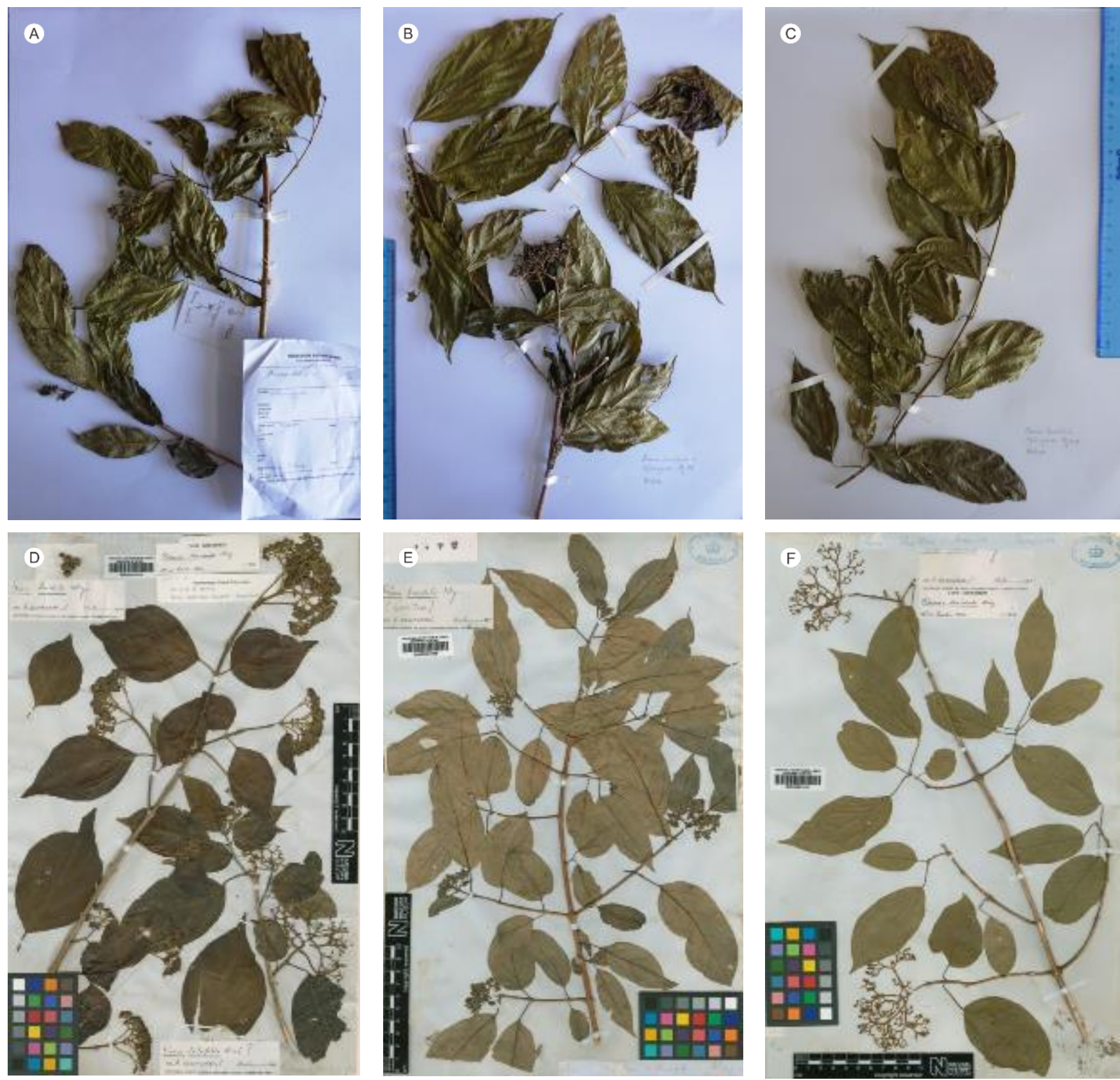

Figure 5. Herbarium of Premna lucidula from Mt. Nglanggeran (A, B, C). Lectotype of Premna lucidula, collection of NHM (natural History Museum) London BM 00001424 (D), BM000901425 (E), BM000901426 (F).

Rediscovery of Premna lucidula in Mount. Nglanggeran confirm the publication and report the existence Premna lucidula in Java by Miquel (1859). The rareness of herbaria data and study of Premna lucidula made this spesies was treat as synonym of several Premna. De Kock (2013) suggested Premna lucidula Miq are synonym of Premna pubescens. Leeratiwong et al. (2009) stated that Premna lucidula are synonym of Premna hamiltonii inspite of difference he was observed. Premna hamiltonii have charachters as follows: Having longer hairs on the midrib of adaxial surface of leaves, the abaxial surface of leaves with both spreading villose and pubescent hairs and pubescent ovary, while the latter has mostly adpressed pubescent hairs on the midrib of adaxial surface of leaves, the abaxial surface of leaves occurring glabrous to sparse, pubescent hairs and glabrous ovary.

Rajendra (2002) illustrated Premna lucidula from Sikkim India. He stated that: Premna lucidula is represented in Indian herbaria by very few, old collections only, and has not been collected from the States of Sikkim and West Bengal after the turn of this century. This seems to be a rare species in India. 


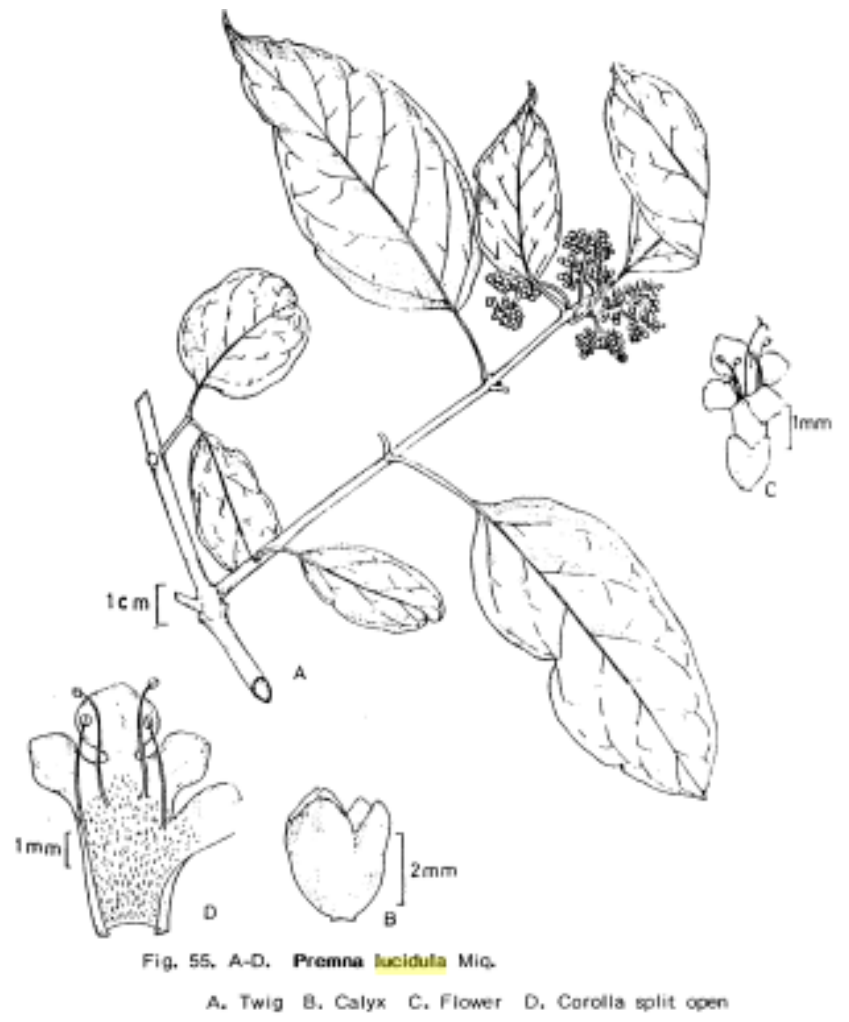

Figure 6. Sketch of Premna lucidula (Rajendra, 2002)

Based on BM type herbarium 00001424, BM000901425, BM000901426 (Natural History Museum, 2017) and drawing of Rajendra (2002) in Figure 7, the authors confirm that Premna that had found in Mt. Nlganggeran Gunungkidul is Premna lucidula. According to this study, based on life specimen observation, herbarium, herbarium type, it was concluded that the plant is Premna lucidula Miq., which is a separate species and not a synonym of Premna pubescens Blume as delivered by de Kok (2013). In his report, de Kock (2013) state that Premna lucidula is placed as a synonym of Premna pubescens. The simplification and revision of Premna taxonomy should be prudent and require fresh specimen data to avoid erroneous simplification. As stated by Tan and $\mathrm{Li}$ (2014), the genus of Premna is "still ranks among the most taxonomically difficult and complicated genera of Lamiaceae". Such cases also occur in the genus Fagraea in the Loganiaceae family (Widodo \& Luthfi, 2016). Backer \& Bakhuizen (1965) has described that Premna lucidula is a distinctive species from Premna pubescens. Backer \& Bakhuizen's (1965) description of Premna lucidula needs to be complemented so as not to cast doubt on the identification of this species. This paper reinforces and supports the determination of Rajendran and Daniel (2002) about Premna lucidula Miq.

\section{Taxonomic Information}

Premna lucidula Miq., FI. Ind. Bat. 2: 898. 1858; Backer \& Bakh.f., FI. Java 2: 604. 1965. - Type: Pacitan
Java, Horsefield.BM00001424, BM000901425, BM000901426.

\section{Description}

Deciduous shrubs or small tree, 3-7 m tall; lenticelate stem, branches and branchlets 4 angled; young parts thinly short hairy. Leaves opposite; petiole $2-6 \mathrm{~cm}$ long, glabrous to pubescent; lamina ovate-oblong, 8-15 $\times$ 4-8 $\mathrm{cm}$, base rounded-obtuse or cuneate rather long acuminate, margins entire, apex acute; short-hairy on the surface of the midrib; otherwise subglabrous on both surface. Flowers creamy white, 3-4 $\mathrm{mm}$ across, subsessile on terminal corymbs that are composed of 4-6 decussate-opposite dichotomously branched cymes to 8 $15 \times 10-15 \mathrm{~cm}$., calyx cuplike, 2 lipped, pubescent outside. Corolla infundibular, glabrous outside, greenish white; 2 lipped, upper lip 2-2 1/2 mm, lower lip. C $3 \mathrm{~mm}$, densely hairy on throat. Stamens 4, didynamous. G(2), ovary globose; style slender, stigma 2 lobed. Drupe globose $5 \mathrm{~mm}$ across, black when mature.

\section{Note}

Premna lucidula in Mount Nglanggeran are flowering on November-January.

\section{Concervation}

The existence of this plant in situ is threatened by human activity due to the increased interest in the site as a tourist destination. It is necessary to information people about the position and status of this plant in local ecosystems.

\section{CONCLUSIONS}

In conclusion, Premna lucidula are found on Mount Nglanggeran Yogyakarta. Morphological characteristics habit, leaves, twigs, flowers of Premna lucidula from Mount Nglanggeran show similarity to Premna lucidula collection of Horsefield from Pacitan Jawa (BM00001424, BM000901425, BM000901426) (Natural History Museum, 2017). This finding support lectotypyfication the herbarium by Rajendra as a type herbarium of Premna lucidula and deny the report that it is synonym to Premna pubescens dan Premna hamiltonii. The existence Premna lucidula on Mount Nglanggeran complements and recovers the description of Backer and Bakhuizen van den Brink (1965) about Premna lucidula.

\section{ACKNOWLEDGEMENTS}

The authors thank the Herbarium Natural History Museum, London (BM) on herbarium photograph. Thanks also to Sugeng Handoko as chairman of ecotourism Mount Nglanggeran, Yogyakarta on exploration for the identification of plants in the region. 


\section{REFERENCES}

Backer CA, Bakhuizen van den Brink Jr RC. 1965. Flora of Jawa (Spermatophytes Only) (Vol II). N. V. P. Noordhoff, Groningen.

de Kok R, 2013. The genus Premna L. (Lamiaceae) in the Flora Malesiana area. Kew Bulletin Vol. 68: 55-84.

Leeratiwong C, Chantaranothai P, Paton AJ. 2009. A Synopsis of the Genus Premna L. (Lamiaceae) in Thailand. The Natural History Journal of Chulalongkorn University 9 (2): 113-142.

Miquel F A W. 1859-60. Flora van Nederlandsch Indie. (Vo. I, II, III). C. G. van der Post. Amsterdam

Natural History Museum (2014). Dataset: Collection specimens. Resource: Specimens. Natural History Museum Data Portal (data.nhm.ac.uk). http://dx.doi.org/10.5519/0002965 (accessed 1 September 2017).

Premna lucidula Miq. in The Catalogue of Life Partnership (2017). Catalogue of Life. Checklist Dataset https://doi.org/10.15468/rffz4x accessed via GBIF.org on 2017-11-06

Rajendran A, Daniel P. 2002. The Indian verbenaceae: a taxonomic revision. Dehra Dunn, India.

Simpson MG. 2006. Plant systematics. Elsevier, Amsterdam.

Singh G. 2010. Plant systematics. Science Publishers, Jersey.

Takhtajan. 2009. Flowering plant. Springer, St. Petersburg.

Tan Y, Li B. 2014. Taxonomic studies on the genus Premna (Lamiaceae) in China-I: the identities of $P$. fulva and $P$. Tapintzeana. Phytotaxa 173 (3): 207-216.

The Plant List. 2013. Premna lucidula. Version 1.1. Published on the Internet. http://www.theplantlist.org/ (accessed 1 September 2017).

Widodo, Luthfi MJ. 2016. Morphological study of Fagraea ceilanica (Gentianaceae) in Mount Nglanggeran. Biodiversitas. Vol. 17 (2): 454-460. 
THIS PAGE INTENTIONALLY LEFT BLANK 